Yet with over $\$ 100$ million of their own money already spent, the 733 utilities involved have been pushing for construction to go ahead. The level of jingoism has been high. Visitors to the Clinch River site are given a free coffee mug inscribed "we are fighting for energy independence",. And in a letter expressing their support, 17 members of a group known as Scientists and Engineers for Secure Energy, headed by ex-president of the National Academy of Sciences, Frederick Seitz, gave as one of their reasons that "in view of recent political developments in certain Western countries, particularly France, the Clinch River Project may become the only reliable technological undertaking of its kind in the free world".

But in the end the personal support of Senator Howard Baker has been decisive. As characterized in the House budget bill, the liquid metal fast breeder reactor (LMFBR) will be one of a series of steps designed to bring US breeder technology in line with that of other industrialized nations.

The most recent of these steps has been the successful operation last December of the Fast Flux Test Facility (FFTF) at the Department of Energy's Hanford Reservation in Washington State. Late in March of this year, the $\mathbf{4 0 0}$ megawatt test facility emerged with flying colours from a safety test in which the reactor was shut down from full power, and the main coolantcirculating pumps were turned off. Construction of the Clinch River reactor, say its supporters, is the logical next step.

In approving the Clinch River funding (and therefore channelling support away from solar energy and conservation research which the Science and Technology Committee in the House of Representatives had preferred), the House authorized an initial $\$ 15$ million for the planning of a 1,000 megawatt reactor.

How much future support for the breeder programme will, in fact, be forthcoming from the Reagan Administration remains uncertain. In his formal presentations, budget director David Stockman has forsworn his earlier statements and repeated the Administration's support for LMFBR. In private, however, $\mathrm{Mr}$ Stockman and his officials at the Office of Management and Budget are said to be strongly opposed to further substantial government subsidies of the nuclear industry, including its fast breeder plans, preferring that the utilities should pay.

Meanwhile opponents have not given up the fight. They are giving wide publicity to the findings of a congressional investigation team that some of the contractors may have been overcharging for components already supplied. In the wings is a debate about whether the reactor meets the new siting requirements introduced by the Nuclear Regulatory Commission after the Three Mile Island accident. Congress may have made up its mind, but the public debate is far from over. David Dickson
Research ethics and safety

\section{Changing the guard}

\section{Washington}

In a small but symbolic way, last Thursday may turn out to be a significant turning-point in the history of public controls on genetic engineering. Meeting in Bethesda, Maryland, an advisory committee to the National Institutes of Health (NIH) decided to recommend to its parent body, the Recombinant DNA Advisory Committee (RAC), a further substantial relaxation of the safety controls applied to recombinant DNA research.

Meanwhile 50 miles away, in the depths of the Virginia countryside, a presidential commission established to look at the ethical problems raised by biomedical advances has suggested the establishment of a new body - possibly at an international level - charged to seek a social consensus on the various dilemmas which the expanding clinical use of genetic engineering techniques will raise.

The RAC subcommittee was set up at a meeting of the full committee in May to discuss proposals for a significant relaxation in the safety guidelines made by $\mathrm{Dr}$ David Baltimore of the Massachusetts Institute of Technology and Dr Allan Campbell of Stanford University (Nature 7 May, p.3).

The subcommittee, whose recommendations will now be discussed at the next full meeting of RAC in September, did not agree that NIH guidelines should be made voluntary. However, they did suggest that detailed rules for the composition of local institutional biohazards committees (IBC) be removed.

If eventually approved by $\mathrm{NIH}$, this would mean that research institutions would no longer be required to include "public interest" representatives, for example, on their IBC (although many would probably continue to do so). It could also mean that the responsibilities of the IBC to ensure compliance with the guidelines could be delegated to a single institutional biosafety officer.

The subcommittee also supported a proposal to eliminate from the guidelines a detailed listing of containment procedures, and its replacement by a statement that such procedures should follow recommendations being developed by the Center for Disease Control for experiments using the host or the vector separately.

In other cases the subcommittee proposed that P1 containment levels be used, and that a statement be included about donor DNA, saying that if there is clear evidence that the donor DNA will significantly alter the pathogenicity of the host, then the appropriate containment level will be applied.

Some of the suggestions approved by the subcommittee - for example that all prohibitions requiring special permission from the director of NIH, including work with

\section{Ziman speaks out}

Professor John Ziman on Monday strongly criticized the Royal Society, of which he is a fellow, for sluggishness on human rights issues. He was addressing the All-Party Parliamentary Committee for Soviety Jewry at a special award ceremony in the House of Commons, at which he received on behalf of Dr Viktor Brailovskii, who last month was sentenced to five years' Siberian exile, a Henry Moore lithograph entitled "for courage in defence of freedom".

Professor Ziman earlier this year had received, in conjunction with Dr John Humphrey (until recently deputy director of the National Institute of Medical Research) and lawyer Paul Sieghart, the second annual Airey Neave award, which will finance a study of freedom in science. He was therefore an obvious proxy for $\mathrm{Dr}$ Brailovskii who, until his arrest last November, had acted as host and organizer of the Sunday seminar for Jewish "refusnik" scientists denied emigration visas but dismissed from their academic posts after applying for them.

Professor Ziman said it would have been more appropriate that $\mathrm{Dr}$ Brailovskii's proxy should have been not a private scientist such as himself but the president of the Royal Society in his official capacity. He recalled that $\mathrm{Dr}$ Aleksandr Voronel', the founder of the Sunday seminar, said in Britain shortly after being allowed to emigrate in 1974 that "the seminar is the only true representative of free and independent science in the Soviet Union". The Royal Society, whose official aim is "improving human knowledge", should therefore, said Professor Ziman, give the fullest possible support to the seminar - support which, so far, it has been reluctant to afford.

Vera Rich

cultures over 10 litres, be eliminated from the guidelines - went further than Dr Baltimore and Dr Campbell had proposed to RAC. Others, such as the continuation of local biosafety procedures and the recommendation that the guidelines remain mandatory for scientists working with NIH funds, are more conservative.

Any decisions by RAC at its next meeting will be subsequently published in the Federal Register for public comment. After that, the matter will rest with $\mathrm{Dr}$ Richard M. Krause, director of the National Institute of Allergy and Infectious Diseases, who was given full responsibility for ensuring compliance with the guidelines by $\mathrm{Dr}$ Donald Fredrickson when he resigned as NIH director on 30 June.

As the safety debate is being wound down at NIH, a complementary discussion about the steps necessary to prevent undesirable clinical applications of genetic manipulation techniques has been getting 
under way with the President's Commission for the Study of Ethical Problems in Medicine and Biomedical and Behavioral Research.

The commission was asked last year to look at the ethical issues raised by genetic engineering by President Carter's science adviser, Dr Frank Press, following a letter to the President from three church groups expressing concern that recent advances in genetic research meant that "those who would play God will be tempted as never before". Since then the churches involved have not demonstrated a particularly close interest, but public concern has been stimulated by various press reports of potential new surgical techniques.

At last week's meeting the members discussed a draft report on the ethical and social aspects of genetic engineering. And although reluctant to raise unnecessary fears, they agreed that the implications were likely to be significant - for example in terms of the potential ability of an individual to alter the genetic characteristics of his or her descendants.

Most commission members agreed that there was a need for a wider public dissemination of information about the potential effects of new clinical techniques. Also that it might be appropriate for some type of advisory body to indicate areas in which caution should be used.

There was less of a consensus on whether it was desirable that such a body should suggest that certain types of experiments for example the cloning of a human being - should be prohibited. Some, for example, suggested that any attempt at what the draft report described as the "control of evolution" should be proscribed; others pointed out the phrase was so broad as to include many currentlyaccepted practices, such as the treatment of diabetes with insulin.

The commission also debated whether discussions should take place at an international level. There was general agreement, however, that achieving international consensus on the boundary between acceptable and unacceptable practices would be even more difficult than at a national level.

David Dickson

\section{New substance regulations}

\section{Industry complains}

The British Chemical Industries Association is protesting vigorously at the draft on the notification of new chemical substances drawn up by the Health and Safety Executive. The association claims that the draft regulations would mean the end of research and development in the British chemical industry.

The draft regulations were published last February, when comments from interested parties were invited by the end of this month. They are an attempt to bring British practice into line with a directive of the European Commission, whose aim is to protect "man and the environment" from the potential hazards of new substances. Although the directive deals chiefly with the protection of the consumer, the Health and Safety Executive is (given its remit) primarily concerned with the protection of workers' health.

Thus the British regulations would require industry to notify not only all new manufactured substances but also all new intermediates in chemical processes. The Chemical Industries Association complains that the extra costs involved will drive research and development away from Britain. The dilemma is, however, real. The Health and Safety Executive says that intermediates must be tested if existing regulations to protect workers from potential hazards are to be put on a more formal basis than required by the Health and Safety at Work Act.

The consultative document is precise about the tests required for new chemicals. Manufacturers would be required to assess the toxicity of substances by $\mathrm{LD}_{50}$ tests, provide data on skin and eye irritability, tests for mutagenicity and possibly carcinogenicity and teratogenicity. They would also have to provide data on biodegradability. The executive estimates that the total cost would be about $£ 45,000$ per substance.

The objections of the chemical industry appear to centre more on the range of chemicals covered than the direct cost. As well as chemical intermediates, the draft regulations cover pharmaceuticals, foodstuffs and pesticides, all of which are excluded from the European directive on the grounds that they are covered by other regulations. The Health and Safety Executive's argument is that such assessments relate only to specific uses, and are not necessarily sufficient.

After the July deadline, the chemical industry will also be arguing for a strengthening of the provisions for preserving confidentiality. The association is concerned that valuable data, especially those on intermediates which would provide information on novel process routes, could fall into competitors' hands.

So far, few other bodies have put in comments, but the trade unions and environmentalists will also be having their say. The controversy aroused by the chemical industry's response, however, suggests that further negotiation will be needed before the regulations are in a final form and that the European Commission's 18 September deadline for the implementation of legislation will not now be met.

The European Commission is at the same time going ahead with its plan to compile a catalogue of all chemicals manufactured in Europe. Thereafter, industry will be required to notify the commission of all new chemicals manufactured during the past ten years that are not included, a ruling that will apply even in countries that will not have introduced their own legislation.

Judy Redfearn
UK pharmaceutical industry

\section{Keeping up}

“'Britain's medicine makers have brought out an 'unfashionable' annual report - it tells a success story." So says the cheery publicity blurb announcing the 1980-81 report of the Association of the British Pharmaceutical Industry (ABPI). The claimed success is an increase in the value of exports of pharmaceuticals to $£ 745.4$ million in $1980,16.7$ per cent up on the sales in 1979 , and representing a $£ 523$ million surplus of exports over imports.

Evidence of success is rare enough in British industry and the bouncy confidence affected by ABPI is likely to please a government eager for good news. And the industry seems to be getting its views across with some aplomb. Already this year the industry has had a victory in the form of new regulations governing the granting of the clinical trial certificates which must be obtained before new drugs can be tested clinically. From March, the certification process requires simpler documentation and data requirements have been reduced.

In another area of concern to ABPI, Mrs Sally Oppenheim, Minister of State for Consumer Affairs, has said that the government will try to include a "state of the art" defence in the EEC directive on product liability. The objective is that manufacturers should not be held liable for injuries to health caused by a product which could not be termed "defective" in the light of scientific knowledge when the drug was put onto the market.

The supposed main benefits to be gained by the simpler clinical certification rules are a reduction in the 10 to 12 years now needed for a new drug to reach the patient (a debatable improvement, especially after Fisons' withdrawal of Proxicromil when it was all but on the market, see Nature 12 March, p.81), and a stimulus to encourage development of drugs to treat less common diseases.

However, the most tangible effect of relaxations in control of drugs in clinical trials is likely to be an increase in the numbers of trials conducted in the United Kingdom rather than in other, less restrictive, countries. This is one factor to be considered by multinational companies when deciding whether to invest in Britain or go elsewhere. At present investment in research in the United Kingdom is holding up well, with $£ 16$ million to be invested by Merck, Sharp and Dohme in a neurobiology research centre near Harlow, £5 million by Upjohn in expanding facilities at West Crawley, $£ 10$ million by the Wellcome Foundation in a chemical research laboratory in Beckenham, and £3.3 million by Roche in improving research facilities at Welwyn Garden City. But competition between the developed countries for the favours of the researchbased companies can only increase.

Charles Wenz 